University of Nebraska - Lincoln

DigitalCommons@University of Nebraska - Lincoln

Roman L. Hruska U.S. Meat Animal Research

U.S. Department of Agriculture: Agricultural Center

Research Service, Lincoln, Nebraska

$1-1-2021$

\title{
Use of bedding materials in beef bedded manure packs at hot and cold ambient temperatures: Effects on odorous volatile organic compounds and odor activity values
}

\author{
Jeff P. Jaderborg \\ University of Minnesota Twin Cities \\ Mindy J. Spiehs \\ USDA ARS Roman L. Hruska U.S. Meat Animal Research Center, mindy.spiehs@ars.usda.gov \\ Bryan L. Woodbury \\ USDA ARS Roman L. Hruska U.S. Meat Animal Research Center \\ Alfredo DiCostanzo \\ University of Minnesota Twin Cities \\ David B. Parker \\ USDA ARS Roman L. Hruska U.S. Meat Animal Research Center
}

Follow this and additional works at: https://digitalcommons.unl.edu/hruskareports

Part of the Beef Science Commons, and the Meat Science Commons

Jaderborg, Jeff P.; Spiehs, Mindy J.; Woodbury, Bryan L.; DiCostanzo, Alfredo; and Parker, David B., "Use of bedding materials in beef bedded manure packs at hot and cold ambient temperatures: Effects on odorous volatile organic compounds and odor activity values" (2021). Roman L. Hruska U.S. Meat Animal Research Center. 564.

https://digitalcommons.unl.edu/hruskareports/564

This Article is brought to you for free and open access by the U.S. Department of Agriculture: Agricultural Research Service, Lincoln, Nebraska at DigitalCommons@University of Nebraska - Lincoln. It has been accepted for inclusion in Roman L. Hruska U.S. Meat Animal Research Center by an authorized administrator of DigitalCommons@University of Nebraska - Lincoln. 


\title{
Use OF BEDDING MATERIALS IN BEEF BEDDED MANURE PACKS AT HOT AND COLD AMBIENT TEMPERATURES: EFFECTS ON ODOROUS VOLATILE ORGANIC COMPOUNDS AND ODOR ACTIVITY VALUES
}

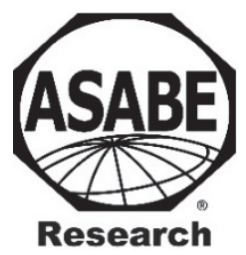

\author{
J. P. Jaderborg, M. J. Spiehs, B. L. Woodbury, A. DiCostanzo, D. B. Parker
}

HighLIGHTS

- Aromatic compounds generated $72.6 \%$ of the total odor activity values (OAVs) over time.

- Cold treatments had significantly lower total OAVs than hot treatments regardless of the age of the bedded pack.

\begin{abstract}
Beef cattle producers are beginning to raise cattle in confinement facilities such as slatted-floor barns, hoop barns, and mono-slope facilities. Hoop and mono-slope facilities typically use bedding packs as part of their manure management system, with crop residues being the most commonly used bedding material. This study was conducted to determine the effects of bedding material, i.e., corn stover (CS), bean stover (BS), wheat straw (WS), or pine wood chips (PC), and environmental ambient temperature, i.e., cold $\left(15^{\circ} \mathrm{C}\right)$ or hot $\left(30^{\circ} \mathrm{C}\right)$, on the concentrations of odorous volatile organic compounds (VOCs) in air samples collected in the headspace above lab-scale bedded packs over a 42-day period. Total aromatic compounds, sulfide compounds, straight-chain fatty acids (SCFAs), and branched-chain fatty acids (BCFAs) were measured and used to calculate total odor activity values $(O A V S)$ for each bedding and temperature effect. No significant three-way interactions for bedding material $x$ ambient temperature $\times$ age of bedded pack were observed. Significant bedding material $x$ ambient temperature interactions were observed for total aromatic compounds and total sulfide compounds $(p=0.0455$ and $p=0.0083$, respectively). The concentration of total aromatic compounds was greater for all hot treatments compared

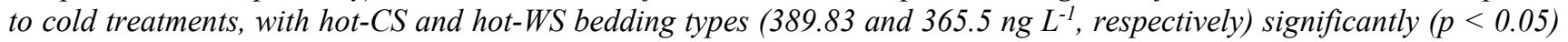
greater than all other bedding types, while total aromatic compounds were lowest $\left(87.09 \mathrm{ng} L^{-1}\right)$ for $B S$ across cold treatments. Total sulfide compounds from cold-PC $\left(51.69 \mathrm{ng} \mathrm{L}^{-1}\right)$ were significantly $(p=0.0143)$ greater than all other treatments. Within hot treatments, total sulfide compounds were similar across all bedding materials. Total SCFAs for both cold and hot treatments decreased significantly from weeks 4 to 6. Total SCFA concentrations within weeks were significantly $(p<0.0001)$ greater for WS and CS compared to BS and PC but similar across bedding materials at week 6. Total BCFA concentrations from bedded packs containing CS and WS were significantly $(p<0.0001)$ higher at week 4 compared to concentrations from bedded packs containing BS or PC. As bedded packs aged, total BCFA concentrations for all bedding materials were similar at week 6. Total OAVs decreased over time for both hot and cold treatments, although cold treatments had significantly $(p<0.0001)$ lower total OAVs regardless of the age of the bedded pack. Aromatic compounds generated $72.6 \%$ of the total OAV over the 42-day study. Bedding types BS and PC had the lowest total OAVs across all weeks. The results indicate that feedlot operators maintaining bedded pack facilities will achieve the greatest overall odor reduction when using BS or PC bedding material, no matter the ambient temperature.
\end{abstract}

Keywords. Bedding, Beef, Odor, Volatile organic compounds.

Submitted for review on 9 September 2020 as manuscript number PAFS 14299 approved for publication as a Research Article by the Plant, Animal, \& Facility Systems Community of ASABE on 3 February 2021.

Mention of company or trade names is for description only and does not imply endorsement by the USDA. The USDA is an equal opportunity provider and employer.

The authors are Jeff P. Jaderborg, Graduate Student, Department of Animal Science, University of Minnesota, St. Paul, Minnesota; Mindy J. Spiehs, Research Animal Scientist, and Bryan L. Woodbury, Research Agricultural Engineer, USDA-ARS U.S. Meat Animal Research Center, Clay Center, Nebraska; Alfredo DiCostanzo, Professor, Department of Animal Science, University of Minnesota, St. Paul, Minnesota; David B. Parker, Research Agricultural Engineer, USDA-ARS Conservation and Production Research Laboratory, Bushland, Texas. Corresponding author: Mindy Spiehs, USDA-ARS U.S. Meat Animal Research Center, P.O. Box 166, State Spur 18D, Clay Center, NE 68933; phone: 402-7624271; e-mail: mindy.spiehs@ars.usda.gov.
I $\mathrm{n}$ the last decade, nearly $50 \%$ of the feedlot growth reported by beef producers in the U.S. Upper Great Plains has been achieved by building confinement facilities (Euken et al., 2015). One type of beef confinement facility is deep-bedded monoslope barns that use locally available crop residues as bedding material. In most cases, availability and cost are the main factors for producers to consider when selecting a bedding material. Common types of crop residue bedding materials used in the U.S. Upper Great Plains are corn stover, bean stover, and wheat straw (Doran et al., 2010). Many factors influence odorous emissions from livestock facilities, with the type of bedding material cited as a possible influence on odorant emissions (Spiehs et al., 
2013, 2014, 2017). Anaerobic degradation of bedded packs mixed with manure are sources of odorous compounds that are considered offensive by humans (Mackie et al., 1998).

Airborne volatile organic compounds (VOCs) have been established as primary contributors to livestock odors, specifically phenolic and indolic odorous compounds from manure traveling downwind from concentrated animal feeding operations (CAFO) (Wright et al., 2005; Bulliner et al., 2006; Koziel et al., 2006; Parker, 2008; Parker et al., 2016). Warmer ambient temperatures during summer (above $30^{\circ} \mathrm{C}$ ) tend to increase VOC levels as a result of increased microbial activity compared to winter temperatures (below $15^{\circ} \mathrm{C}$ ). When evaluating manure from beef feedlot surfaces, Woodbury et al. (2015) reported that VOC emissions increased as ambient temperature rose from $5^{\circ} \mathrm{C}$ to $35^{\circ} \mathrm{C}$.

The type of bedding material also influences VOC emissions. Inclusion of pine chips with corn stover bedding at greater than $40 \%$ reduced branched-chain fatty acid (BCFA) concentrations, and as little as $10 \%$ inclusion of pine chips reduced skatole by $64 \%$ (Spiehs et al., 2017). However, inclusion of pine chips over $80 \%$ resulted in excess carbon that increased the $\mathrm{C}: \mathrm{N}$ ratio to $27.5: 1$ at 42 days. A final C:N ratio of 24:1 is recommended to support the soil microorganisms needed for nutrient recycling in the soil (USDA, 2011). Ratios above 24:1 may create a temporary nitrogen deficiency for growing crops. In addition, $100 \%$ pine chips significantly increased odorous sulfur compounds. When pine wood chips were used as a bedding material in place of corn stover, the odor activity value (OAV) was reduced by $73 \%$ over a 42 day study (Spiehs et al., 2014). However, research conducted by Spiehs et al. (2012) showed that concentrations of total BCFAs, aromatic compounds, sulfur compounds, and calculated OAVs did not differ between bedding containing corn stover, pine wood chips, and various combinations of these two materials. While current literature has demonstrated that temperature and bedding material can independently affect gas and odor emissions from feedlot surfaces, no research has examined how these two factors interact with one another.

The objective of this study was to determine the effect of bedding material and environmental ambient temperature on concentrations of odorous VOCs in air samples collected in the headspace above lab-scale bedded packs over a 42-day period.

\section{MATERIALS AND MeTHODS BEDDING MATERIAL}

Corn stover (CS), bean stover (BS), wheat straw (WS), and pine wood chips (PC) were used in this lab-scale bedded pack study. Locally sourced CS, BS, and WS were processed in a chipper/shredder (Earthquake, Ardisam, Inc.) before being sifted through a $6.35 \mathrm{~mm}$ screen to remove fines, as described by Spiehs et al. (2014). Kiln-dried PC were purchased (Ozark Shavings Co.) and used without further processing.

\section{LAB-SCALE Bedded PaCKS}

Lab-scale bedded packs were built using linear low-density polyethylene (LLDPE) plastic containers $(0.43 \mathrm{~m}$ high and a $0.38 \mathrm{~m}$ diameter), as previously described by Spiehs (2018) (fig. 1). Six $1 \mathrm{~cm}$ holes spaced equally around the circumference of the containers and approximately $5 \mathrm{~cm}$ from the top of the containers allowed air movement through the containers (Spiehs, 2018). Using lab-scale bedded packs allowed temperature to remain constant and increased replication compared to a field study.

Bedding treatment material ( $400 \mathrm{~g})$ was initially added to the containers to create the base of the bedded pack. Three times per week, on Monday, Tuesday, and Thursday for the Tuesday sample collection group (chambers A and B) and on Tuesday, Wednesday, and Friday for the Wednesday sample collection group (chambers C and D), $300 \mathrm{~g}$ of cattle feces and $300 \mathrm{~mL}$ of cattle urine were added to the bedded pack surface (fig. 2). Urine $\mathrm{pH}$ was adjusted to 7.4 using $6 \mathrm{M}$ sodium hydroxide $(\mathrm{NaOH})$ to simulate the $\mathrm{pH}$ level of fresh urine from feedlot cattle (Spiehs, 2018). Bedding (200 g) was added once weekly on the day of sample collection after sample collection was completed. After the addition of feces, urine, and bedding material, the bedded pack was mixed for $30 \mathrm{~s}$ using a plastic-covered $5.08 \mathrm{~cm}$ steel rod to imitate animal activity. Once weekly, bedding and air samples were collected to measure VOCs before the addition of feces, urine, and bedding material.

Each 42-day study used four environmental chambers to control ambient temperature and humidity (Brown-Brandl et al., 2011; fig. 3). Two environmental chambers (chambers B and D) were used for the hot treatments $\left(30^{\circ} \mathrm{C}\right.$ with $12^{\circ} \mathrm{C}$ dew point), and two environmental chambers (chambers $\mathrm{A}$ and C) were used for the cold treatments $\left(15^{\circ} \mathrm{C}\right.$ with $10^{\circ} \mathrm{C}$ dew point). Temperatures were chosen to resemble the typical summer temperature (hot treatments) and spring or fall temperature (cold treatments) in the U.S. Upper Great Plains. Each chamber maintained a steady ambient temperature and humidity level throughout the study, as described previously by Brown-Brandl et al. (2011). There were eight lab-scale bedded packs, two of each bedding material treatment in each environmental chamber during each of four 42day periods, creating 16 experimental units per bedding treatment. All bedded packs were stored in a common room at constant temperature of $18^{\circ} \mathrm{C}$ before being placed in their respective chambers on day 21 . Lab-scale bedded packs

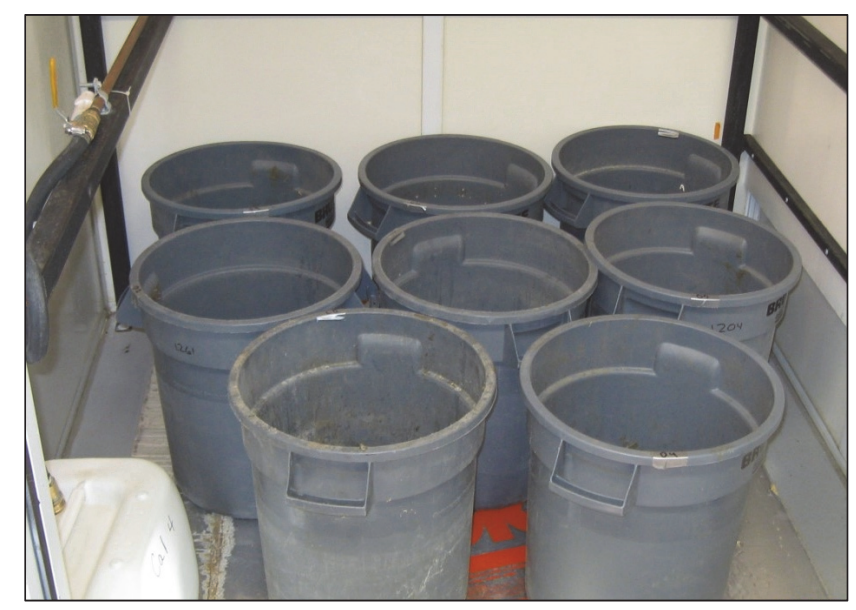

Figure 1. Lab-scale bedded packs containing bean stover, corn stover, pine wood chips, and wheat straw in environmental chambers. 


\begin{tabular}{|c|c|c|c|}
\hline $\begin{array}{l}\text { Environmental } \\
\text { Chamber "A" }\end{array}$ & $\begin{array}{l}\text { Environmental } \\
\text { Chamber "B" }\end{array}$ & $\begin{array}{l}\text { Environmental } \\
\text { Chamber "C" }\end{array}$ & $\begin{array}{l}\text { Environmental } \\
\text { Chamber "D" }\end{array}$ \\
\hline COLD $15^{\circ} \mathrm{C}$ & НОT $30^{\circ} \mathrm{C}$ & COLD $15^{\circ} \mathrm{C}$ & HOT $30^{\circ} \mathrm{C}$ \\
\hline $\begin{array}{c}\text { Feces, urine and } \\
\text { bedding material } \\
\text { added Monday, } \\
\text { Tuesday, and } \\
\text { Thursday }\end{array}$ & $\begin{array}{l}\text { Feces, urine and } \\
\text { bedding material } \\
\text { added Monday, } \\
\text { Tuesday, and } \\
\text { Thursday }\end{array}$ & $\begin{array}{l}\text { Feces, urine and } \\
\text { bedding material } \\
\text { added Tuesday, } \\
\text { Thursday, and } \\
\text { Friday }\end{array}$ & $\begin{array}{l}\text { Feces, urine and } \\
\text { bedding material } \\
\text { added Tuesday, } \\
\text { Thursday, and } \\
\text { Friday }\end{array}$ \\
\hline $\begin{array}{c}\text { Samples collected } \\
\text { Tuesday }\end{array}$ & $\begin{array}{c}\text { Samples collected } \\
\text { Tuesday }\end{array}$ & $\begin{array}{c}\text { Samples collected } \\
\text { Wednesday }\end{array}$ & $\begin{array}{c}\text { Samples collected } \\
\text { Wednesday }\end{array}$ \\
\hline
\end{tabular}

Figure 2. Lab-scale bedded pack layout, material addition, and sample collection times in environmental chambers A, B, C, and D. The four bedding materials were corn stover (CS), bean stover (BS), wheat straw (WS), and pine wood chips (PC).

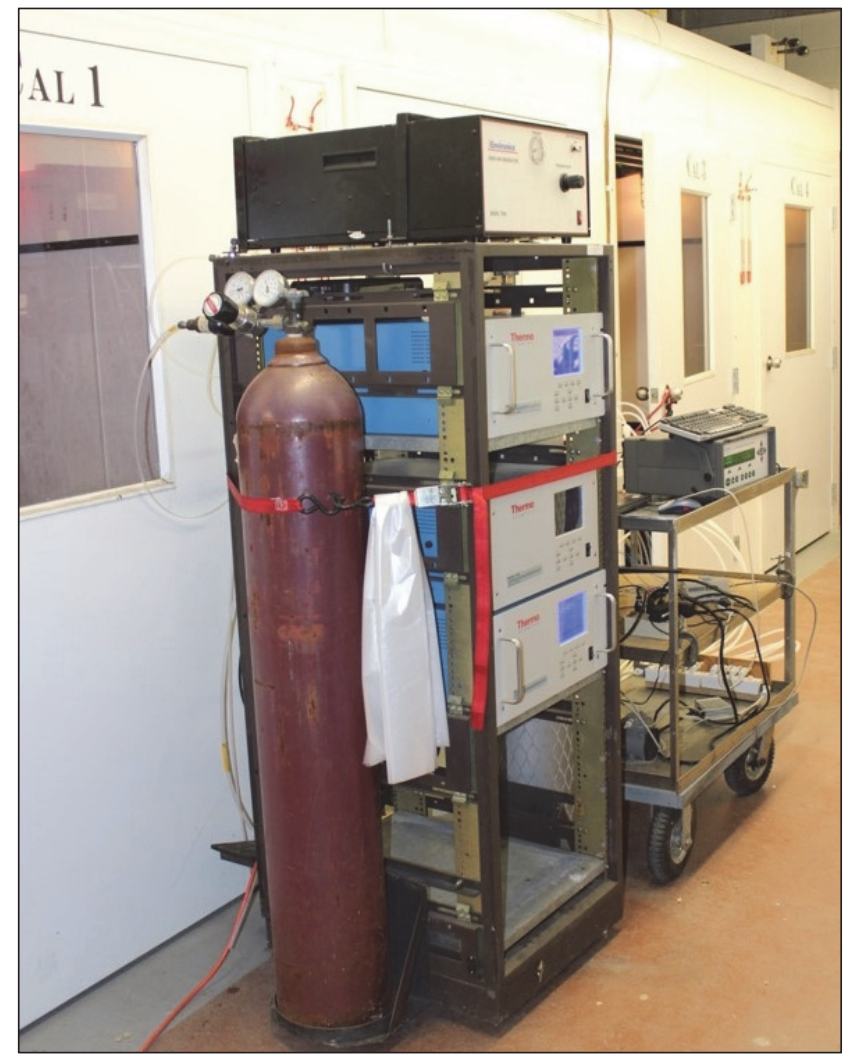

Figure 3. Sampling equipment and four environmental chambers used to house lab-scale bedded packs containing bean stover, corn stover, pine wood chips, and wheat straw.

were not placed in the chambers and sampled until day 21 because space in the chambers was limited. Previously published lab-scale bedded pack research has shown little to no change in VOC emissions from bedded packs before day 21 (Spiehs et al., 2013, 2014).

\section{SAMPle COLlection}

Air samples were collected on Tuesday (chambers A and B) and Wednesday (chambers C and D) before feces, urine, and fresh bedding were added to the bedded packs. Collection of VOC samples was performed using a single stainless steel sorbent tube connected to an inlet port on the stainless steel hemispherical flux chamber with flexible plastic tubing. The preconditioned stainless steel sorbent tubes $(89 \mathrm{~mm}$ $\times 6.4 \mathrm{~mm}$ OD) were filled with Tenax TA sorbent (Markes International) and had brass storage caps with polytetrafluorethylene (PTFE) ferrules (Spiehs, 2018). Headspace air samples were pulled through the sorbent tubes at a flow rate of $75 \mathrm{~mL} \mathrm{~min}-1$ for $5 \mathrm{~min}$ for a sample volume of $0.375 \mathrm{~L}$ using a vacuum pump (Pocket Pump 210 Series, SKC Inc.; Parker et al., 2013a; Spiehs, 2018).

The sorbent tubes were analyzed for VOCs, including acetic acid, butyric acid, propionic acid, isobutyric acid, isovaleric acid, valeric acid, hexanoic acid, heptanoic acid, phenol, $p$-cresol, indole, skatole, dimethyl disulfide (DMDS), and dimethyl trisulfide (DMTS), using a thermal desorptiongas chromatography-mass spectrometry system (Parker et al., 2013a, 2013b). The TD system was a Unity 2 (Markes International) with an autosampler (Ultra 2, Markes International) coupled to a GCMS (7890A/5975C, Agilent Technologies), as previously described by Parker et al. (2013b).

OAVs were determined from the individual VOCs values analyzed using gas chromatography, as described by Spiehs et al. (2014). The OAV is the ratio of the concentration of a single chemical compound to the odor detection threshold (ODT) for that chemical (Friedrich and Acree, 1998; Trabue et al., 2006) and was calculated using equation 1 :

$$
\mathrm{OAV}=(\text { Concentration of } \mathrm{VOC}) /(\mathrm{ODT})
$$

The ODT is the published ODT of a specific VOC (van Gemert, 2003; Parker et al., 2013b; Spiehs et al., 2014). For this study, the ODT values reported by Spiehs et al. (2014) were used in the calculation of OAV. The ODT values for acetic acid, propionic acid, isobutyric acid, butyric acid, isovaleric acid, valeric acid, hexanoic acid, and heptanoic acid were 578, 106, 38, 6.9, 2.3, 8.8, 69, and $60 \mathrm{ng} \mathrm{L}^{-1}$, respectively. The ODT values used to calculate OAV for phenol, $p$-cresol, indole, skatole, DMDS, and DMTS were $206,1.3,2.1,0.48,12$, and $2 \mathrm{ng} \mathrm{L}^{-1}$, respectively. A summation of individual OAVs was used to produce a total OAV for each bedded pack, as described by Parker et al. (2013b). The total OAV was used to estimate differences in odor from each bedded pack (Spiehs et al., 2014), although it does not account for synergistic or complex 
interactive effects from the mixing odorous chemicals (DiSpirito et al., 1994; Powers, 2001).

\section{Statistical AnAlysis}

Data were analyzed as a $2 \times 4$ factorial with repeated measures in time using the GLIMMIX procedure of SAS (SAS Institute, Inc.). Bedding material, temperature, age of bedded pack, replication, period, bedding material $\times$ temperature, bedding material $\times$ age of bedded pack, and bedding material $\times$ temperature $\times$ age of bedded pack were included in the model. Covariate structure was tested using the following structures: variance components of Toeplitz, autoregressive and compound symmetry to find the lowest Akaike information criteria (AIC) value. Compound symmetry was found to provide the lowest AIC value. When significant differences were detected, Fisher's least significant difference (LSD) test was used for means separation. Bedded pack was the experimental unit. Differences were considered significant when $\mathrm{p}<0.05$ and tendencies at $\mathrm{p}$-values ranging from $\mathrm{p}=0.05$ to $\mathrm{p}<0.10$.

\section{RESULTS AND DISCUSSION ARomatic Compounds}

Total aromatic compounds, $p$-cresol, and skatole had significant $(\mathrm{p}=0.0455, \mathrm{p}=0.0460$, and $\mathrm{p}=0.0389$, respectively) two-way interactions for bedding material type by ambient temperature (table 1). Greater total aromatics (fig. 4), $p$-cresol, and skatole concentrations were measured in the headspace of all bedding material treatments in the hot ambient temperature compared to the cold temperature. Bedded packs with the hot-WS and hot-CS treatments produced significantly greater total aromatic, $p$-cresol, and skatole concentrations than any other treatment. Bedded packs with cold-BS bedding produced the least total aromatic, $p$-cresol,

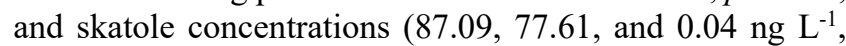
respectively). Warmer ambient temperature provides a more conducive environment for microbial fermentation, which is a key contributor to the hot bedded pack treatments having a $125 \%$ greater total aromatic concentrations compared to the cold treatments. Miller et al. (2003) reported that E. coli bacterial populations from pen floor manure at a beef cattle feedlot were lowest during the winter (4.63 $\left.\log \mathrm{CFU} \mathrm{g}^{-1}\right)$ and highest during summer (7.61 log CFU g $\left.{ }^{-1}\right)$.

Additionally, a significant $(\mathrm{p}=0.0309)$ interaction of ambient temperature $\times$ age of bedded pack was observed for 4-ethylphenol concentrations in the headspace. Within weeks 4, 5, and 6, the 4-ethylphenol concentrations from bedded packs maintained at hot ambient temperature were significantly higher than for packs at cold temperature. Across weeks 4,5 , and 6 , the 4-ethylphenol concentrations were similar within treatments at cold ambient temperature $(0.85,0.68$, and $0.63 \mathrm{ng} \mathrm{L}^{-1}$, respectively). While the 4-ethylphenol concentrations at hot ambient temperature decreased significantly from weeks 4 to 5 (2.34 vs. $1.59 \mathrm{ng} \mathrm{L}^{-1}$, respectively), they were similar between weeks 5 and 6 (1.59 vs. $1.63 \mathrm{ng} \mathrm{L}^{-1}$, respectively). This differed from previous research by Spiehs et al. (2012), who reported that the concentrations of aromatic compounds from bedded packs were similar at weeks 0 and 3 before increasing at week $6\left(16.8,15.4\right.$, and $27.2 \mathrm{ng} \mathrm{L}^{-1}$, respectively). Additionally, previous research by Spiehs et al. (2014) reported similar concentrations of aromatic compounds at weeks 0,3 , and $6\left(0.5,0.5\right.$, and $0.8 \mathrm{ng} \mathrm{L}^{-1}$, respectively) for lab-scale bedded packs.

The indole and phenol concentrations were not observed to produce a multi-variable interaction (table 1). A significant single-variable difference was observed for indole concentration with ambient temperature and age of bedded pack $(p<0.0001$ and $p=0.0014$, respectively). Indole concentration was significantly $(\mathrm{p}<0.0001)$ greater in the hot environment compare to cold ( 0.73 vs. $0.32 \mathrm{ng} \mathrm{L}^{-1}$, respectively), with the highest indole concentration $\left(0.70 \mathrm{ng} \mathrm{L}^{-1}\right)$ measured at week 6 and the lowest $\left(0.36 \mathrm{ng} \mathrm{L}^{-1}\right)$ at week 5. Significant $(p<0.0001)$ single-variable differences for phenol concentration were observed with bedding material type, ambient temperature, and age of bedded pack. Phenol concentration in the headspace above WS was significantly $(p=0.0044)$ greater than for all other bedding material types $\left(29.30 \mathrm{ng} \mathrm{L}^{-1}\right)$. Treatments maintained at hot versus cold temperatures produced significantly greater phenol concentration (26.86 vs. $14.19 \mathrm{ng} \mathrm{L}^{-1}$, respectively). Additionally, as the bedded packs aged from weeks 4 to 5 , the phenol concentration decreased significantly $(\mathrm{p}<0.0001)$, while being similar from weeks 5 to $6\left(25.48,17.82\right.$, and $18.28 \mathrm{ng} \mathrm{L}^{-1}$, respectively).

\section{SULFIDE COMPOUNDS}

O’Neill and Phillips (1992) identified 168 compounds that contribute to odor nuisance from livestock facilities. Of the ten compounds with the lowest odor detection thresholds, $60 \%$ contained sulfur. Undigested dietary sulfur is excreted evenly between urine and feces. However, as dietary sulfur intake increases, the percentage of sulfur excreted in urine increases compared to feces (Bouchard and Conrad,

Table 1. Probabilities (expressed as p-values) that aromatic and sulfide compounds concentrations in headspace air from lab-scale bedded packs were affected by the main effects and treatment interactions. ${ }^{[a]}$

\begin{tabular}{|c|c|c|c|c|c|c|c|c|c|c|}
\hline Treatment Factors & Phenol & $p$-Cresol & $\begin{array}{l}\text { 4-Ethyl } \\
\text { Phenol }\end{array}$ & Indole & Skatole & $\begin{array}{c}\text { Total } \\
\text { Aromatic } \\
\text { Compounds }\end{array}$ & $\begin{array}{l}\text { Dimethyl } \\
\text { Disulfide }\end{array}$ & $\begin{array}{l}\text { Dimethyl } \\
\text { Trisulfide }\end{array}$ & $\begin{array}{c}\text { Total } \\
\text { Sulfide } \\
\text { Compounds }\end{array}$ & $\begin{array}{l}\text { Total } \\
\text { OAV }\end{array}$ \\
\hline Bedding & $<0.0001$ & $<0.0001$ & $<0.0001$ & 0.3246 & 0.0021 & $<0.0001$ & 0.0002 & 0.0304 & 0.0004 & $<0.0001$ \\
\hline Temperature & $<0.0001$ & $<0.0001$ & $<0.0001$ & $<0.0001$ & $<0.0001$ & $<0.0001$ & 0.8701 & $<0.0001$ & 0.9680 & $<0.0001$ \\
\hline Age of bedded pack & $<0.0001$ & $<0.0001$ & 0.0001 & 0.0014 & 0.1085 & $<0.0001$ & 0.8388 & 0.4102 & 0.8265 & $<0.0001$ \\
\hline Bedding $\times$ Temperature & 0.0681 & 0.0460 & 0.0835 & 0.2817 & 0.0389 & 0.0455 & 0.0086 & 0.0150 & 0.0083 & 0.0796 \\
\hline Bedding $\times$ Age of bedded pack & 0.5142 & 0.4981 & 0.4059 & 0.6478 & 0.7081 & 0.4974 & 0.6213 & 0.1399 & 0.6037 & 0.0255 \\
\hline Temperature $\times$ Age of bedded pack & 0.2495 & 0.0752 & 0.0309 & 0.1806 & 0.5281 & 0.0845 & 0.0007 & 0.0246 & 0.0008 & $<0.0001$ \\
\hline Bedding $\times$ Temp $\times$ Age of bedded pack & 0.3248 & 0.3005 & 0.2281 & 0.1995 & 0.4549 & 0.2930 & 0.5934 & 0.8546 & 0.6017 & 0.5864 \\
\hline
\end{tabular}




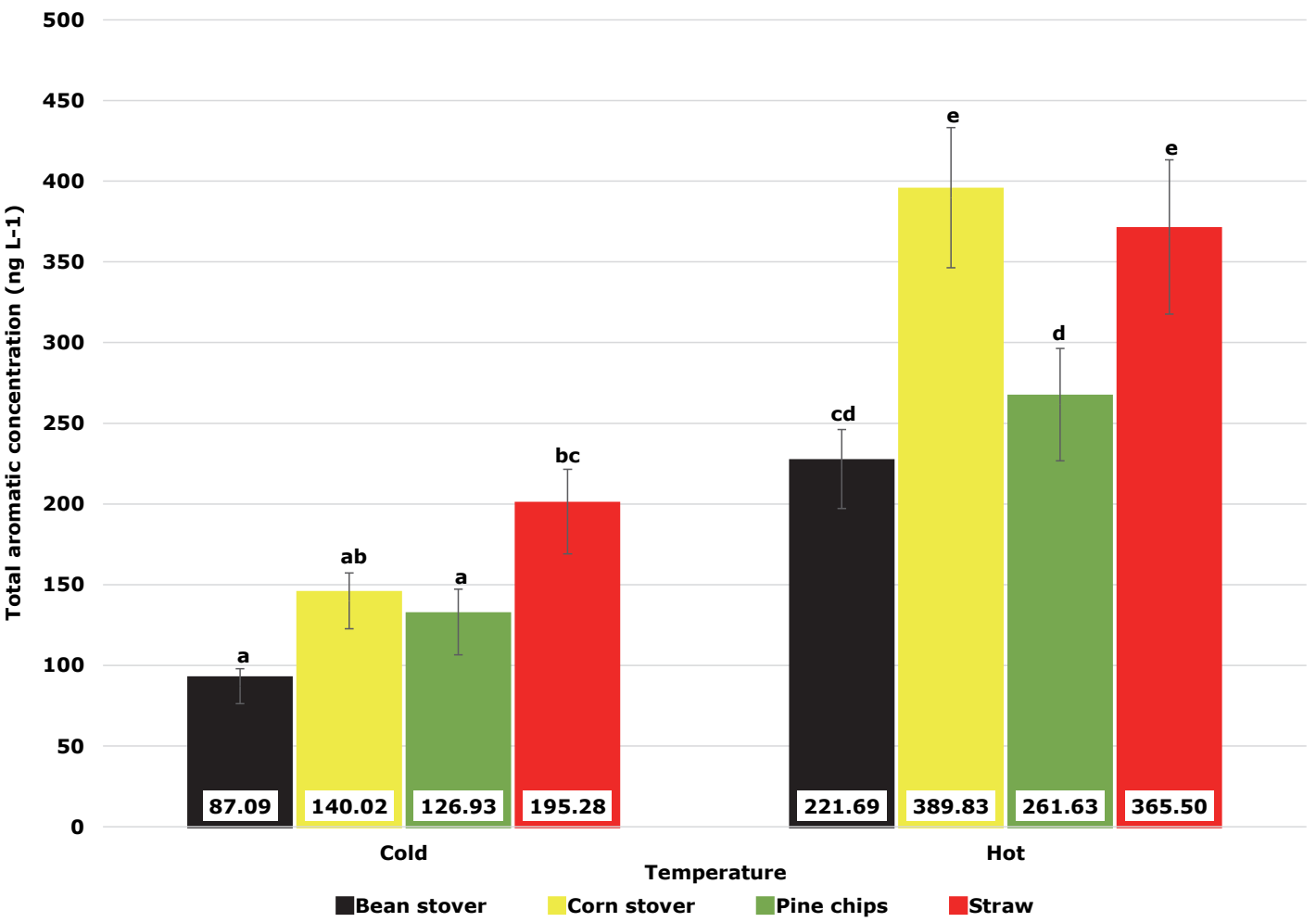

Figure 4. Average concentrations of total aromatic compounds (ng $\left.\mathrm{L}^{-1}\right)$ in headspace air from lab-scale bedded packs containing bean stover, corn stover, pine wood chips, and wheat straw. Bedding material $\times$ ambient temperature treatment interaction $p=0.0455$. Values are least squares means. Error bars indicate standard errors. Different letters indicate significant differences $(p<0.05)$.

1973). Dimethyl disulfide and DMTS are products of the metabolism of sulfur-containing amino acids (methionine and cysteine) by primarily Megasphaera anaerobic bacteria (Mackie et al., 1998). Throughout the 42-day study, DMDS accounted for approximately $95 \%$ of the total sulfide compounds. This was similar to the previous study by Spiehs et al. (2017) in which DMDS accounted for $90 \%$ of the total sulfide concentrations above bedded packs using a mixture of CS and PC bedding material.

There was a significant two-way interaction between ambient temperature and age of bedded pack for total sulfide, DMDS, and DMTS compounds $(\mathrm{p}=0.0008, \mathrm{p}=0.0007$, and $\mathrm{p}=0.0246$, respectively). Concentrations of DMTS were similar across weeks for bedded packs in cold environments, averaging $1.13 \mathrm{ng} \mathrm{L}^{-1}$, but decreased significantly $(p=0.0054)$ from weeks 4 to 6 for bedded packs in hot environments $\left(1.90,1.52\right.$, and $1.34 \mathrm{ng} \mathrm{L}^{-1}$, respectively for weeks 4,5 , and 6). There was a linear increase in DMDS concentrations from weeks 4 to 6 (17.95 and $33.53 \mathrm{ng} \mathrm{L}^{-1}$, respectively) for bedded packs in cold temperatures, while the bedded packs in hot temperatures had a linear decrease in DMDS concentration as the bedded packs aged (36.97 and $16.97 \mathrm{ng} \mathrm{L}^{-1}$, respectively for weeks 4 and 6). While DMDS accounted for the majority of the sulfide compounds emitted from the bedded pack, the total sulfide concentrations in the headspace of bedded packs exposed to the cold temperature increased $\left(18.99,28.20\right.$, and $34.77 \mathrm{ng} \mathrm{L}^{-1}$, respectively for weeks 4, 5, and 6; fig. 5), while bedded packs exposed to the hot temperature saw a reduction over time $(38.87,24.31$, and $18.31 \mathrm{ng} \mathrm{L}^{-1}$, respectively for weeks 4,5 , and 6). As a result, the hot treatments produced the greatest $(p=0.0320)$ total sulfide concentration at week 4 , while at week 6 the cold treatments were significantly $(p=0.0155)$ greater than the hot treatments. Previously, when lab-scale bedded packs were housed at $18^{\circ} \mathrm{C}$ ambient temperature Spiehs et al. (2014) reported that total sulfur concentrations increased from (1.5 to $184.7 \mathrm{ng} \mathrm{L}^{-1}$ ) as bedded packs containing corn stover, pine chips, dry cedar chips, and green cedar chips aged to 42 days. Additionally, Spiehs et al. (2017) observed an increase in total sulfide concentration from initiation of their bedded pack study ( 1.55 to $\left.45.36 \mathrm{ng} \mathrm{L}^{-1}\right)$ as the bedded packs containing combinations of CS and $\mathrm{PC}$ aged to 42 days when stored at $18^{\circ} \mathrm{C}$.

Total sulfide compounds, DMDS, and DMTS produced a significant $(\mathrm{p}=0.0083, \mathrm{p}=0.0086$, and $\mathrm{p}=0.0150$, respectively) bedding material $\times$ ambient temperature interaction. Total sulfide compounds from cold-PC $\left(51.69 \mathrm{ng} \mathrm{L}^{-1}\right)$ were significantly $(\mathrm{p}=0.0143)$ greater than for all other treatments (fig. 6). Similarly, Spiehs et al. (2017) reported the highest sulfur concentration (44.72 $\left.\mathrm{ng} \mathrm{L}^{-1}\right)$ in the headspace of bedded packs containing $100 \%$ PC bedding material compared to other mixtures with corn stover. The bedded packs containing $100 \%$ PC had an ideal environmental $\mathrm{pH}$ of 7.4 to support sulfide-producing bacteria Megasphaera (Zhu, 2000; Spiehs et al., 2017). However, that was not the case in the current study; the $\mathrm{pH}$ of the bedded packs in the cold-PC treatment was $8.1 \mathrm{pH}$. Meanwhile, total sulfide concentrations in the current study were similar across bedding materials within the hot treatments. Because DMDS accounted for most of the total sulfide emissions, the same pattern was evident for DMDS concentrations from the bedded packs. 


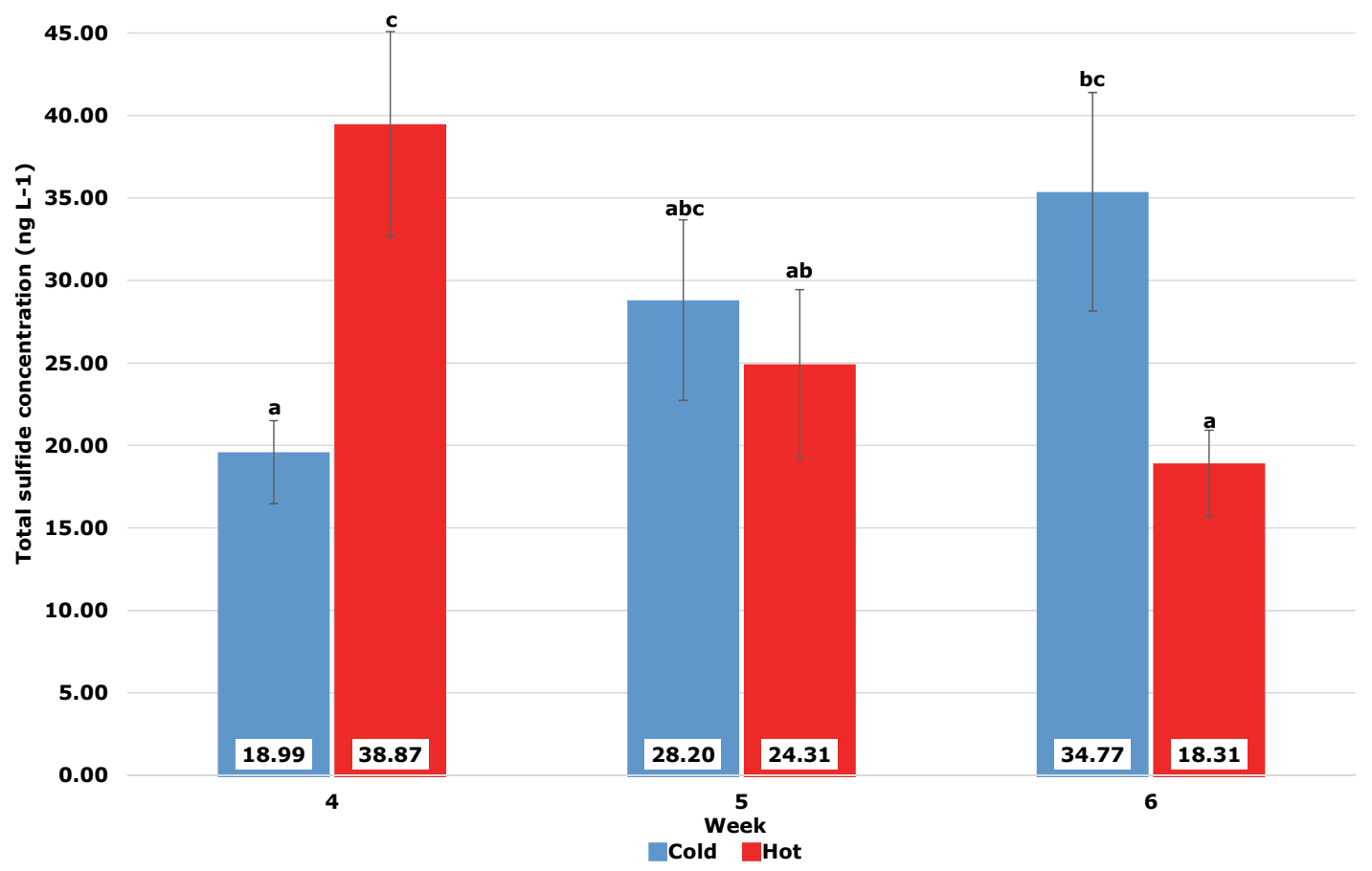

Figure 5. Average concentrations of total sulfides $\left(n g \mathbf{L}^{-1}\right)$ in headspace air from lab-scale bedded packs containing bean stover, corn stover, pine wood chips, and wheat straw. Total sulfides include dimethyl disulfide (DMDS) and dimethyl trisulfide (DMTS). Ambient temperature $\times$ age of bedded pack treatment interaction $\mathbf{p}=\mathbf{0 . 0 0 8 3}$. Values are least squares means. Error bars indicate standard errors. Different letters indicate significant differences $(p<0.05)$.

70

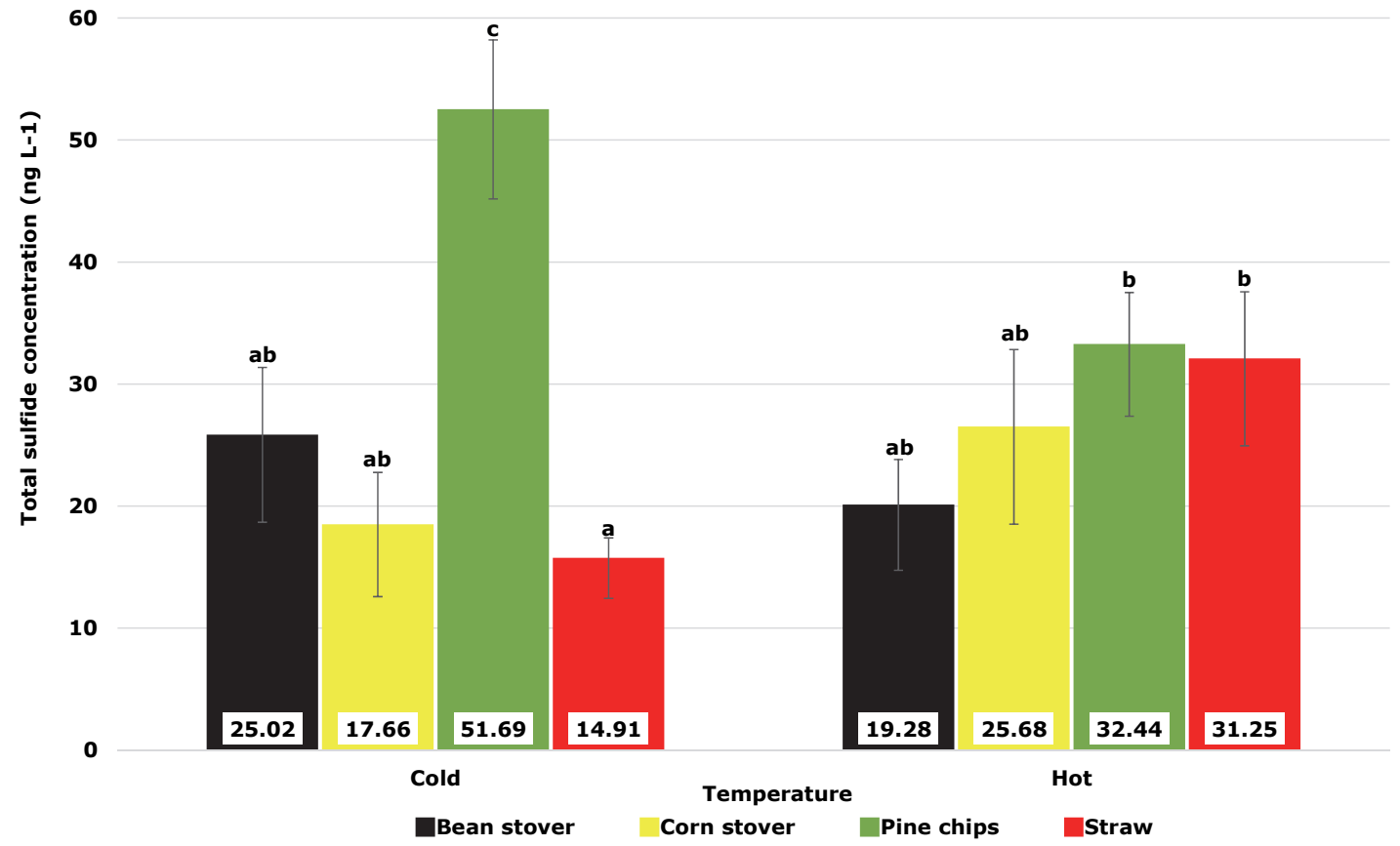

Figure 6. Average concentration of total sulfides $\left(\mathrm{ng} \mathrm{L}^{-1}\right)$ in headspace air from lab-scale bedded packs containing bean stover, corn stover, pine wood chips, and wheat straw. Total sulfides include dimethyl disulfide (DMDS) and dimethyl trisulfide (DMTS). Bedding material $\times$ ambient temperature treatment interaction $\mathbf{p}=\mathbf{0 . 0 0 0 8}$. Values are least squares means. Error bars indicate standard errors. Different letters indicate significant differences $(p<0.05)$. 
The DMTS concentration in the cold environment was highest for PC at $1.40 \mathrm{ng} \mathrm{L}^{-1}$, while BS had the lowest concentration at $0.93 \mathrm{ng} \mathrm{L}^{-1}$. Bedded packs in the hot-WS treatment had the highest DMTS concentration $\left(2.04 \mathrm{ng} \mathrm{L}^{-1}\right)$ but were similar to the hot-CS treatment $\left(1.75 \mathrm{ng} \mathrm{L}^{-1}\right)$.

\section{BRANCHED-ChAIN FATTY ACIDS}

Isovaleric acid and isobutyric acid are contributors to noxious odor emissions from livestock facilities (Parker et al., 2012). Total BCFA concentrations ranged from $6.3 \pm 2.7 \mathrm{ng} \mathrm{L}^{-1}$ to $257.9 \pm 45.0 \mathrm{ng} \mathrm{L}^{-1}$, which is greater than the total BCFA concentration previously reported by Spiehs et al. (2017) for mixtures of CS and PC bedding (5.5 to $8.2 \mathrm{ng} \mathrm{L}^{-1}$ ).

There was a significant two-way interaction between ambient temperature and age of bedded pack for isovaleric acid, isobutyric acid, and total BCFA ( $\mathrm{p}=0.0061, \mathrm{p}=0.0205$, and $\mathrm{p}=0.0118$, respectively; table 2 ). Similar patterns were observed for total BCFA concentrations (fig. 7) as for isovaleric acid and isobutyric acid. The greatest total BCFA concentration was measured at week 4 for the hot treatment (188.0 $\left.\mathrm{ng} \mathrm{L}^{-1}\right)$. For bedded packs in hot environments, isovaleric, isobutyric, and total BCFA concentrations decreased significantly $(\mathrm{p}<0.0001)$ from weeks 4 to 5 but did not decrease further between weeks 5 and 6 . Bedded packs in cold environments had similar isobutyric, isovaleric, and total BCFA concentrations across weeks 4 and 5, as well as being similar at weeks 5 and 6. Additionally, isobutyric, isovaleric, and total BCFA concentrations at week $4(\mathrm{p}<0.0001)$ and week $6(\mathrm{p}<0.05)$ were significantly greater for bedded packs in the hot environment compared to bedded packs in the cold environment. Similar results over time were observed by Spiehs et al. (2012), who reported a significant reduction in BCFA concentrations from weeks 0 to 3 (6.2 to $4.0 \mathrm{ng} \mathrm{L^{-1 }}$, respectively) followed by BCFAs being similar from weeks 3 to 6 (4.0 to $4.6 \mathrm{ng} \mathrm{L}^{-1}$, respectively) when evaluating lab-scale bedded pack mixtures of CS and PC. The change in ambient temperature at week 3 in the current study

Table 2. Probabilities (expressed as p-values) that straight-chain fatty acids (SCFA) and branched-chained fatty acids (BCFA) concentrations in headspace air from lab-scale bedded packs were affected by the main effects and treatment interactions. . $^{[a]}$

\begin{tabular}{ccccccccccccc}
\hline & Acetic & Propionic & Butyric & Valeric & Hexanoic & Heptanoic & Total & Isovaleric & Isobutyric & Total \\
Treatment Factors & Acid & Acid & Acid & Acid & Acid & Acid & SCFA & Acid & Acid & BCFA \\
Bedding & $<\mathbf{0 . 0 0 0 1}$ & $<\mathbf{0 . 0 0 0 1}$ & $<\mathbf{0 . 0 0 0 1}$ & $<\mathbf{0 . 0 0 0 1}$ & $<\mathbf{0 . 0 0 0 1}$ & $\mathbf{0 . 0 0 0 2}$ & $<\mathbf{0 . 0 0 0 1}$ & $<\mathbf{0 . 0 0 0 1}$ & $<\mathbf{0 . 0 0 0 1}$ & $<\mathbf{0 . 0 0 0 1}$ \\
Temperature & $<\mathbf{0 . 0 0 0 1}$ & $<\mathbf{0 . 0 0 0 1}$ & $<\mathbf{0 . 0 0 0 1}$ & $<\mathbf{0 . 0 0 0 1}$ & $<\mathbf{0 . 0 0 0 1}$ & $<\mathbf{0 . 0 0 0 1}$ & $<\mathbf{0 . 0 0 0 1}$ & $<\mathbf{0 . 0 0 0 1}$ & $<\mathbf{0 . 0 0 0 1}$ & $<\mathbf{0 . 0 0 0 1}$ \\
Age of bedded pack & $<\mathbf{0 . 0 0 0 1}$ & $<\mathbf{0 . 0 0 0 1}$ & $<\mathbf{0 . 0 0 0 1}$ & $<\mathbf{0 . 0 0 0 1}$ & $<\mathbf{0 . 0 0 0 1}$ & $<\mathbf{0 . 0 0 0 1}$ & $<\mathbf{0 . 0 0 0 1}$ & $<\mathbf{0 . 0 0 0 1}$ & $<\mathbf{0 . 0 0 0 1}$ & $<\mathbf{0 . 0 0 0 1}$ \\
Bedding $\times$ Temperature & 0.9329 & 0.4332 & 0.1198 & 0.4129 & 0.1723 & 0.3419 & 0.7516 & 0.1286 & 0.1195 & 0.1215 \\
Bedding $\times$ Age of bedded pack & $\mathbf{0 . 0 0 2 3}$ & $\mathbf{0 . 0 1 5 2}$ & $\mathbf{0 . 0 1 2 1}$ & $\mathbf{0 . 0 2 4 8}$ & $\mathbf{0 . 0 3 3 2}$ & 0.2180 & $\mathbf{0 . 0 0 2 5}$ & $\mathbf{0 . 0 2 0 2}$ & $\mathbf{0 . 0 2 2 2}$ & $\mathbf{0 . 0 2 0 5}$ \\
Temperature $\times$ Age of bedded pack & $\mathbf{0 . 0 0 8 8}$ & $\mathbf{0 . 0 0 7 9}$ & $<\mathbf{0 . 0 0 0 1}$ & $\mathbf{0 . 0 0 7 3}$ & $\mathbf{0 . 0 2 6 4}$ & 0.0629 & $\mathbf{0 . 0 0 2 4}$ & $\mathbf{0 . 0 0 6 1}$ & $\mathbf{0 . 0 2 0 5}$ & $\mathbf{0 . 0 1 1 8}$ \\
Bedding $\times$ Temp. $\times$ Age of bedded pack & 0.6727 & 0.5864 & 0.8153 & 0.7567 & 0.7901 & 0.9639 & 0.6907 & 0.6698 & 0.0653 & 0.6588 \\
\hline
\end{tabular}

[a] Treatments consisted of temperature $\left(15^{\circ} \mathrm{C}\right.$ and $\left.30^{\circ} \mathrm{C}\right)$, bedding (bean stover, corn stover, pine wood chips, and wheat straw), and age of bedded pack $(4,5$, and 6 weeks old). Four 42-day experiments were conducted with four bedding material replications per experiment $(n=128)$. Significant effects $(\mathrm{p}<0.05)$ are shown in bold font.

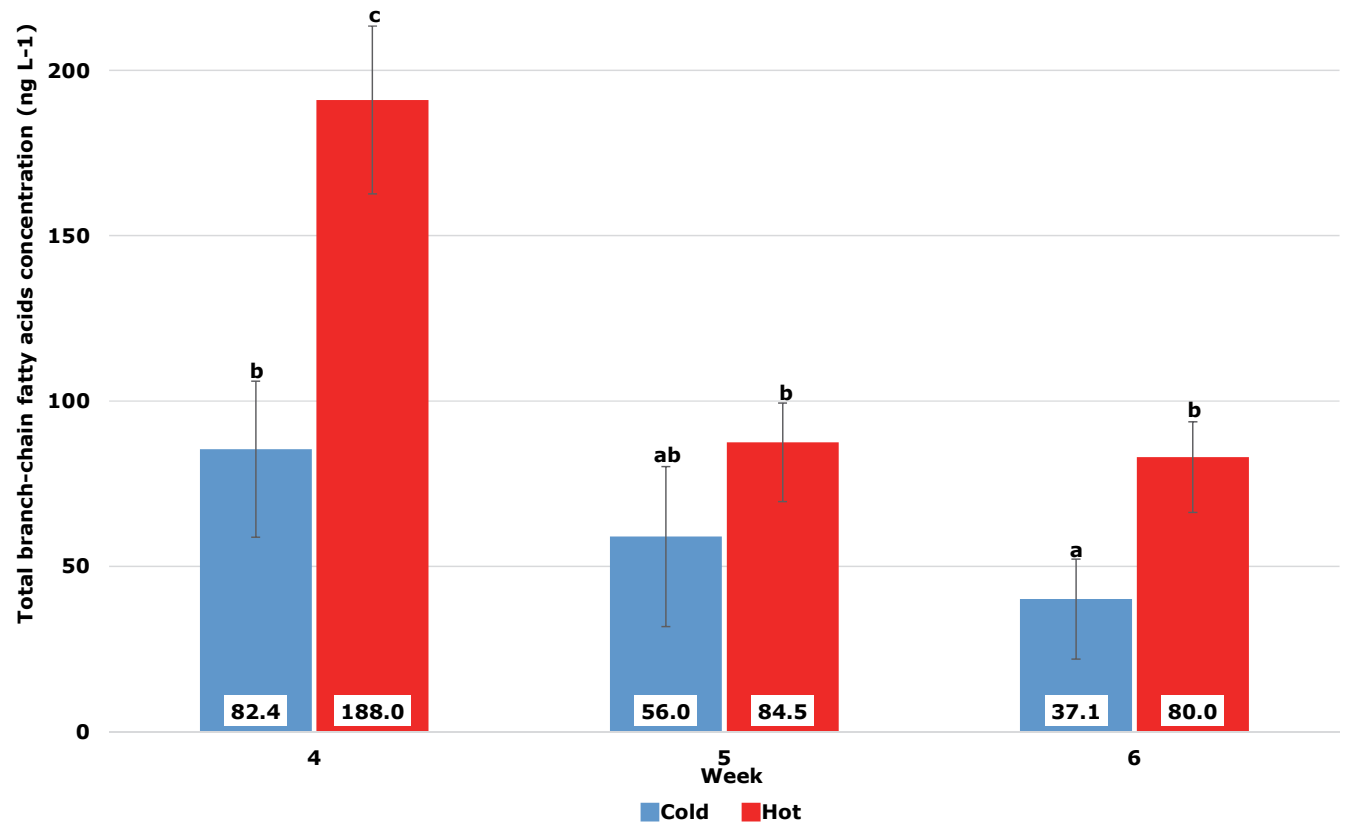

Figure 7. Average concentrations of total branched-chain fatty acids (BCFAs) (ng $\mathrm{L}^{-1}$ ) in headspace air from lab-scale bedded packs containing bean stover, corn stover, pine wood chips, and wheat straw. Total BCFAs include isovaleric acid and isobutyric acid. Ambient temperature $\times$ age of bedded pack treatment interaction $p=0.0118$. Values are least squares means. Error bars indicate standard errors. Different letters indicate significant differences $(p<0.05)$. 


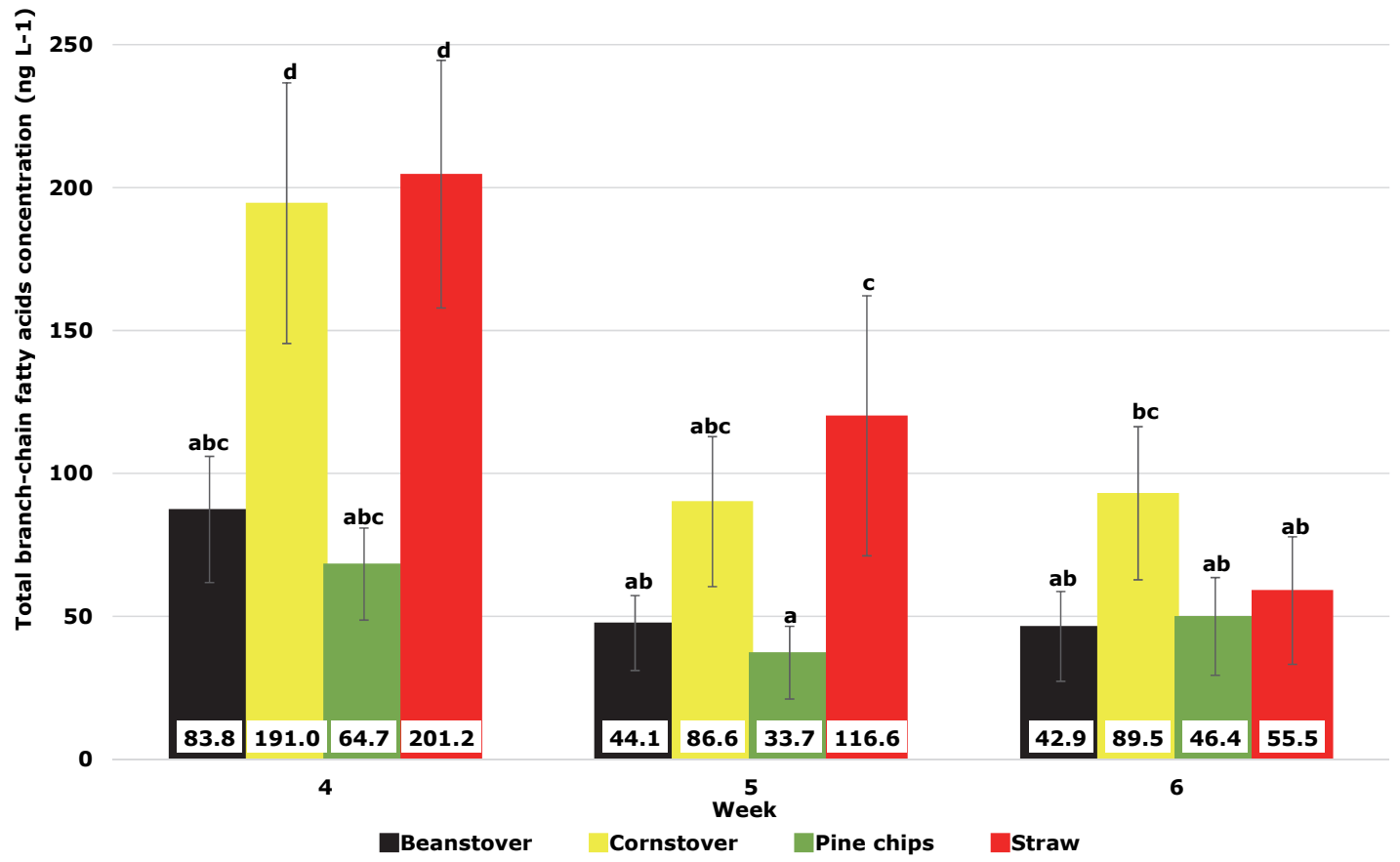

Figure 8. Average concentrations of total branched-chain fatty acids (BCFAs) $\left(n g \mathbf{L}^{-1}\right)$ in headspace air from lab-scale bedded packs containing bean stover, corn stover, pine wood chips, and wheat straw. Total BCFAs include isovaleric acid and isobutyric acid. Bedding material $\times$ age of bedded pack treatment interaction $\mathbf{p}=\mathbf{0 . 0 2 0 5}$. Values are least squares means. Error bars indicate standard errors. Different letters indicate significant differences $(\mathrm{p}<0.05)$.

potentially created an increase in fermentation for hot treatments, causing the total BCFA spike $(\mathrm{p}<0.0001)$ at week 4 compared to weeks 5 and 6.

There was a significant two-way interaction between bedding material and age of bedded pack for isovaleric acid, isobutyric acid, and total BCFA ( $\mathrm{p}=0.0202, \mathrm{p}=0.0222$, and $\mathrm{p}$ $=0.0205$, respectively). Total BCFA concentrations (fig. 8) observed from the bedded packs had similar trends as both isovaleric acid and isobutyric acid. Isovaleric, isobutyric, and total BCFA concentrations from the bedded packs containing CS and WS were significantly $(p<0.0001)$ higher at week 4 compared to the concentrations from bedded packs containing BS or PC. As the bedded packs aged, isovaleric, isobutyric, and total BCFA concentrations for all bedding materials were similar at week 6. Total BCFA, isobutyric, and isovaleric concentrations from bedded packs containing BS and PC were similar across weeks 4, 5, and 6. While total BCFA and isobutyric concentrations from bedded packs containing CS and WS were significantly $(\mathrm{p}<0.05)$ greater at week 4 compared to week 5 and only concentrations from WS were significantly $(\mathrm{p}<0.05)$ greater at week 5 compared with week 6 . The nitrogen content was significantly lower for PC bedding material than for BS, CS, and WS, providing minimal $\mathrm{N}$ for protein fermentation (Spiehs et al., 2013), which is the main substrate for BCFA production (Mackie et al., 1998).

\section{STRAIGHT-ChaIn FATTY ACIDS}

The six key SCFA compounds measured in this experiment were acetic, propionic, butyric, valeric, hexanoic, and heptanoic acids. The fermentation of undigested carbohydrates in feces or bedding material leads to the main production of SCFAs (Mackie et al., 1998; Miller and Varel, 2001). Straight-chain fatty acids are consistently identified as the largest volume producer of VOCs from bedded pack facilities (Spiehs et al., 2014, 2017). The VOC making up the largest volume of SCFA is acetic acid production, which in the current study averaged $51 \%$ to $71 \%$ of the total SCFA concentration found in the headspace above the bedded pack treatments.

The interaction of ambient temperature $\times$ age of bedded pack was significant for acetic, propionic, butyric, valeric, hexanoic, and total SCFA (table 2). Acetic acid, propionic acid, butyric acid, valeric acid, and total SCFA concentrations for both cold and hot treatments decreased significantly $(\mathrm{p}<0.05)$ from weeks 4 to 6 . Across all SCFA compounds, except hexanonic acid and heptanoic acid, concentrations were similar for bedded packs in the hot and cold environments during weeks 5 and 6 . Concentrations of hexanoic acid were similar for hot and cold bedded packs at week 5 but significantly $(p=0.0092)$ higher for bedded packs with the hot treatment compared to the cold treatment during week 6. The highest total SCFA concentration (fig. 9) was observed for the hot treatment at week 4, while the cold treatment at week 6 produced the lowest total SCFA concentration (5196.8 and $651.9 \mathrm{ng} \mathrm{L}^{-1}$, respectively). The bedded packs were moved from a constant $18^{\circ} \mathrm{C}$ to $15^{\circ} \mathrm{C}$ (cold) and $30^{\circ} \mathrm{C}$ (hot) at 3 weeks. The increased temperature for the hot treatment potentially intensified microbial activity, causing increased fermentation of undigested carbohydrates from the 


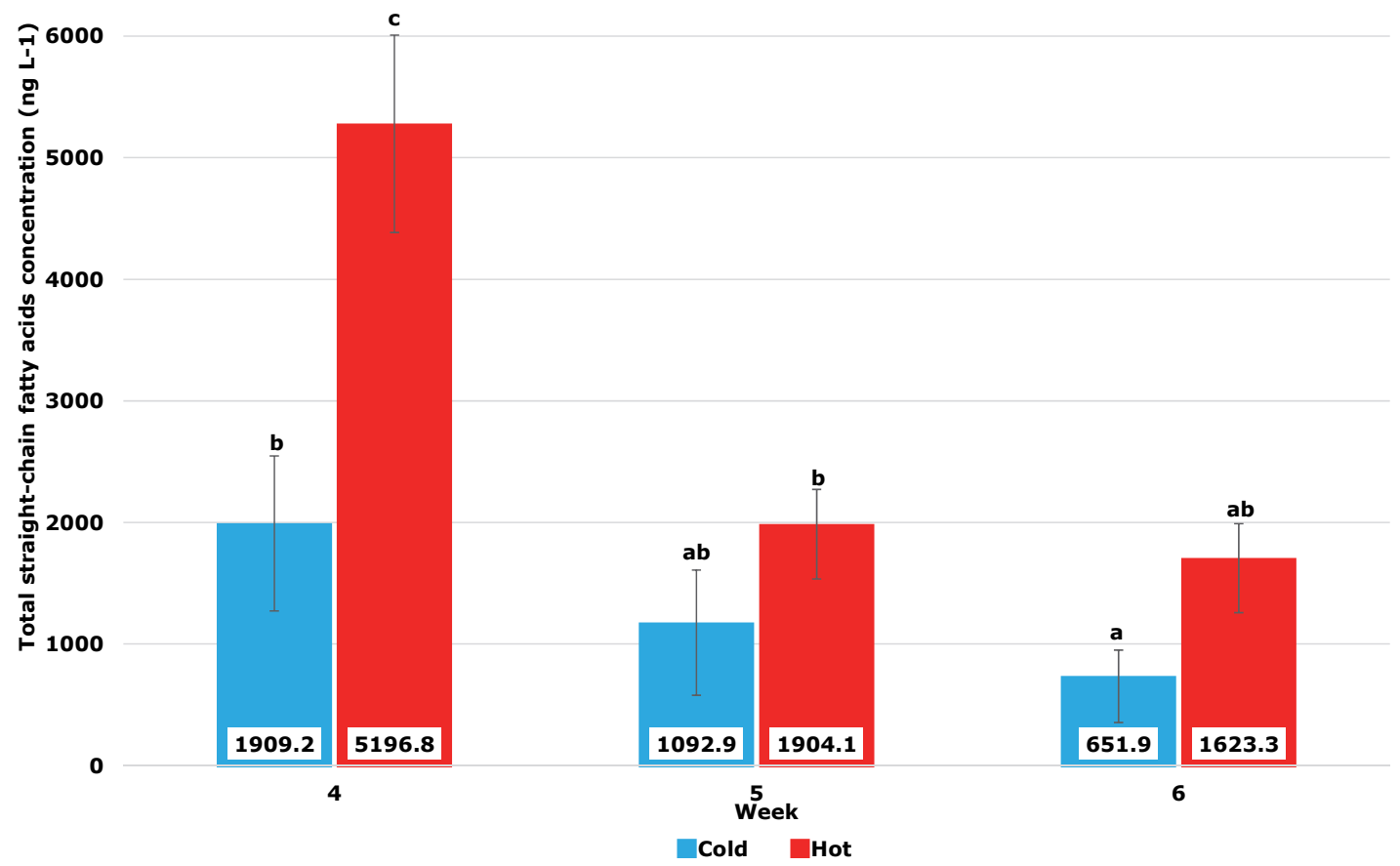

Figure 9. Average concentrations of total straight-chain fatty acids (SCFAs) (ng $\mathrm{L}^{-1}$ ) in headspace air from lab-scale bedded packs containing bean stover, corn stover, pine wood chips, and wheat straw. Total SCFAs include acetic acid, propionic acid, butyric acid, valeric acid, hexanoic acid, and heptanoic acid. Ambient temperature $\times$ age of bedded pack treatment interaction $p=0.0024$. Values are least squares means. Error bars indicate standard errors. Different letters indicate significant differences $(\mathbf{p}<0.05)$.

previous weeks, while the slight reduction in ambient temperature for the cold treatment maintained or limited carbohydrate fermentation. Woodbury et al. (2015) reported that increasing the ambient temperature from $5^{\circ} \mathrm{C}$ to $35^{\circ} \mathrm{C}$ resulted in greater VOC emissions above beef feedlot manure scrapings.

Additionally, a significant interaction of bedding material $\times$ age of bedded pack was observed for acetic, propionic, butyric, valeric, hexanoic, and total SCFA. Concentrations of the individual compounds had a similar trend as the total SCFA concentration (fig. 10). When observing the total SCFA concentration within weeks, concentrations from WS and CS (5,717.4 and 5,053.5 $\mathrm{ng} \mathrm{L}^{-1}$, respectively) were significantly $(\mathrm{p}<0.0001)$ greater than concentrations from BS and PC (1,916.1 and 1,525.0 $\mathrm{ng} \mathrm{L}^{-1}$, respectively) at week 4 . At week 5, the total SCFA concentration from WS was similar to CS, although significantly greater than BS and PC $(p=0.0331$ and $p=0.0313$, respectively). By week 6 , the total SCFA concentrations from all bedding materials were similar. The total SCFA concentrations from BS and CS were similar over time as the bedded packs increased in age. The observation of lower total SCFA concentration from PC compared to CS in this study differed from the previous labscale bedding study by Spiehs et al. (2013) in which the SCFA concentration was greater from PC than from CS (487.6 vs. $282.2 \mathrm{ng} \mathrm{L}^{-1}$, respectively).

There were no multi-variable interactions for heptanoic acid concentration (table 2), although a significant difference was observed for bedding material $(\mathrm{p}=0.0002)$. CS and WS had similar heptanoic acid concentrations $(0.81$ and $0.69 \mathrm{ng} \mathrm{L}^{-1}$, respectively), while BS and $\mathrm{PC}$ also had similar concentrations ( 0.49 and $0.46 \mathrm{ng} \mathrm{L}^{-1}$, respectively), although significantly lower than CS and WS. Heptanoic acid concentrations were significantly $(\mathrm{p}<0.0001)$ greater above bedded packs stored in hot environments than in cold environments ( 0.79 and $0.44 \mathrm{ng} \mathrm{L}^{-1}$, respectively). From weeks 4 to 5 , heptanoic acid concentrations decreased significantly $(\mathrm{p}<0.0001)$ and were similar between weeks 5 to 6 .

The total SCFA concentrations from WS and CS decreased significantly $(\mathrm{p}<0.0001)$ from weeks 4 to 5 and only the concentration from WS continued to decrease significantly $(p=0.0343)$ from weeks 5 to 6 . The total SCFA concentration for the interaction of bedding material $\times$ age of bedded pack had a similar pattern as the total BCFA concentration for this interaction. The observation of a decrease or relative steady concentration over time for both SCFA and BCFA compounds in the current study is dissimilar to previous research by Spiehs et al. $(2014,2017)$. In those 42-day studies, the researchers reported a decrease from weeks 0 to 3 before SCFA and BCFA compounds increased slightly from weeks 3 to 6 . It is likely that the change in ambient temperature at week 3 in the current study increased microbial activity, thereby increasing VFA production at week 4 . Had the current study been conducted until week 8 instead of week 6 , the additional time may have allowed an observed increase in BCFAs similar to the increases at week 6 observed in the previous lab-scale bedded pack studies by Spiehs et al. $(2014,2017)$. 


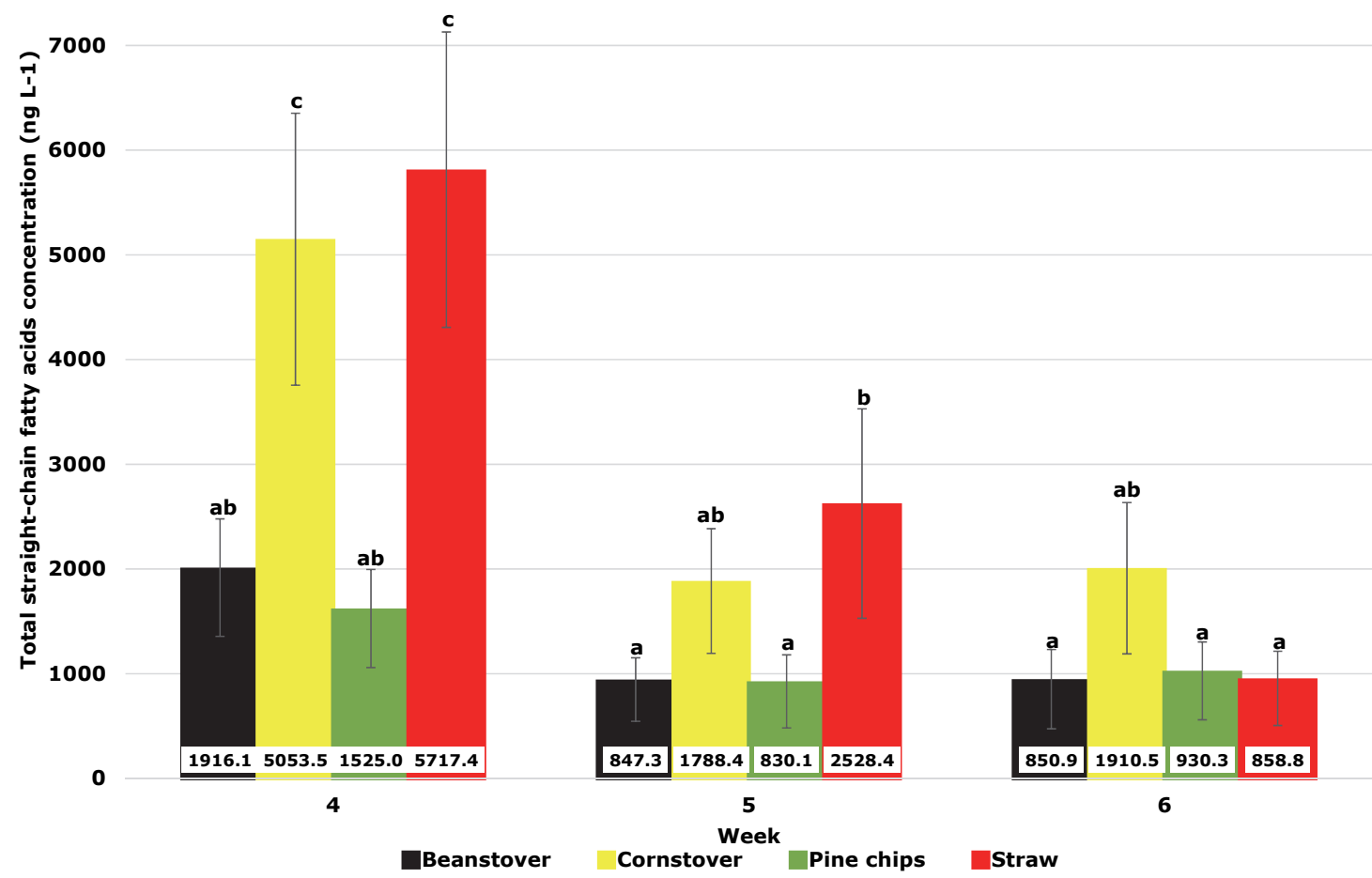

Figure 10. Average concentrations of total straight-chain fatty acids (SCFAs) $\left(n g \mathbf{L}^{-1}\right)$ in headspace air from lab-scale bedded packs containing bean stover, corn stover, pine wood chips, and wheat straw. Total SCFAs include acetic acid, propionic acid, butyric acid, valeric acid, hexanoic acid, and heptanoic acid. Bedding material $\times$ age of bedded pack treatment interaction $\mathbf{p}=\mathbf{0 . 0 0 2 5}$. Values are least squares means. Error bars indicate standard errors. Different letters indicate significant differences $(p<0.05)$.

\section{OdOR ACTIVITY VALUES}

Aromatic compounds made up $72.6 \%$ of the total OAV on average across weeks 4,5 , and 6 , no matter the ambient temperature. Straight-chain fatty acids decreased from $25.1 \%$ to $11.8 \%$ as the bedded pack age increased, and total sulfide compounds increased from $1.5 \%$ to $8.4 \%$ as the bedded pack age increased. Parker et al. (2012) reported similar findings of aromatic compounds accounting for $83 \%$ to $98 \%$ of the total OAV from swine manure in lab-scale shallow pits. Wright et al. (2005) reported that the aromatic compounds $p$-cresol and $p$-ethylphenol were the main contributors to odor monitored up to $250 \mathrm{~m}$ away from swine finishing facilities. Similarly, aromatic compounds were a prominent odorant $20 \mathrm{~m}$ from beef cattle feedyards. Controlling the production of aromatic compound emissions is key to reducing noxious odors from livestock facilities.

There was a significant two-way interaction between ambient temperature and age of bedded pack for total OAV $(\mathrm{p}<0.0001$; table 1). Total OAV for both cold and hot treatments decreased significantly $(p=0.0370$ and $p<0.0001$, respectively) as bedded packs increased in age from weeks 4 to 5 but did not decrease further between weeks 5 and 6 for either temperature treatments (fig. 11). Additionally, total OAV at weeks 4,5 , and 6 was significantly $(\mathrm{p}<0.0001$, $\mathrm{p}<0.0001$, and $\mathrm{p}<0.0001$, respectively) greater for hot treatments compared to cold. The largest total OAV was measured at week 4 (493.1) for the hot treatment. Cold treatments had a similar OAV production at weeks 5 and 6 , which were also the lowest total OAV (136.7 and 106.4, respectively). It appears that the two-way interaction between ambient temperature and age of bedded pack for total OAV was driven by 4-ethylphenol.

A significant $(\mathrm{p}=0.0255)$ interaction for bedding material $\times$ age of bedded pack was observed for total OAV (fig. 12). At week 4 , total OAV was significantly $(\mathrm{p}<0.0001)$ greater for CS and WS (417.5 and 471.4, respectively) compared to BS and PC. Total OAV decreased significantly $(\mathrm{p}<0.05)$ each week as WS bedded packs increased in age (471.4, 284.8 , and 179.0, respectively). Total OAVs for BS, CS, and PC bedded packs decreased significantly $(\mathrm{p}=0.0057, \mathrm{p}<$ 0.0001 , and $p=0.0355$, respectively) from weeks 4 to 5 but were similar at weeks 5 and 6 . Interestingly, the decrease in total OAV over time was contradictory to previously reported total OAVs for CS, PC, dry cedar, and green cedar lab-scale bedded packs by Spiehs et al. (2014), where total OAVs for CS, dry cedar, and green cedar bedding increased as bedded packs aged to day 42. Spiehs et al. (2012) observed that total OAV was similar over time when evaluating lab-scale bedded packs with CS and PC mixtures over a 42-day study. The total OAVs observed in the current study suggest that the use of $\mathrm{BS}$ or PC would have the greatest benefit in reducing overall noxious odors from bedded pack facilities. It appears that SCFAs (fig. 10) had greater influence on the two-way interaction for bedding material $\times$ age of bedded pack for total OAV (fig. 12) compared to aromatic and sulfide compounds in the current study. 


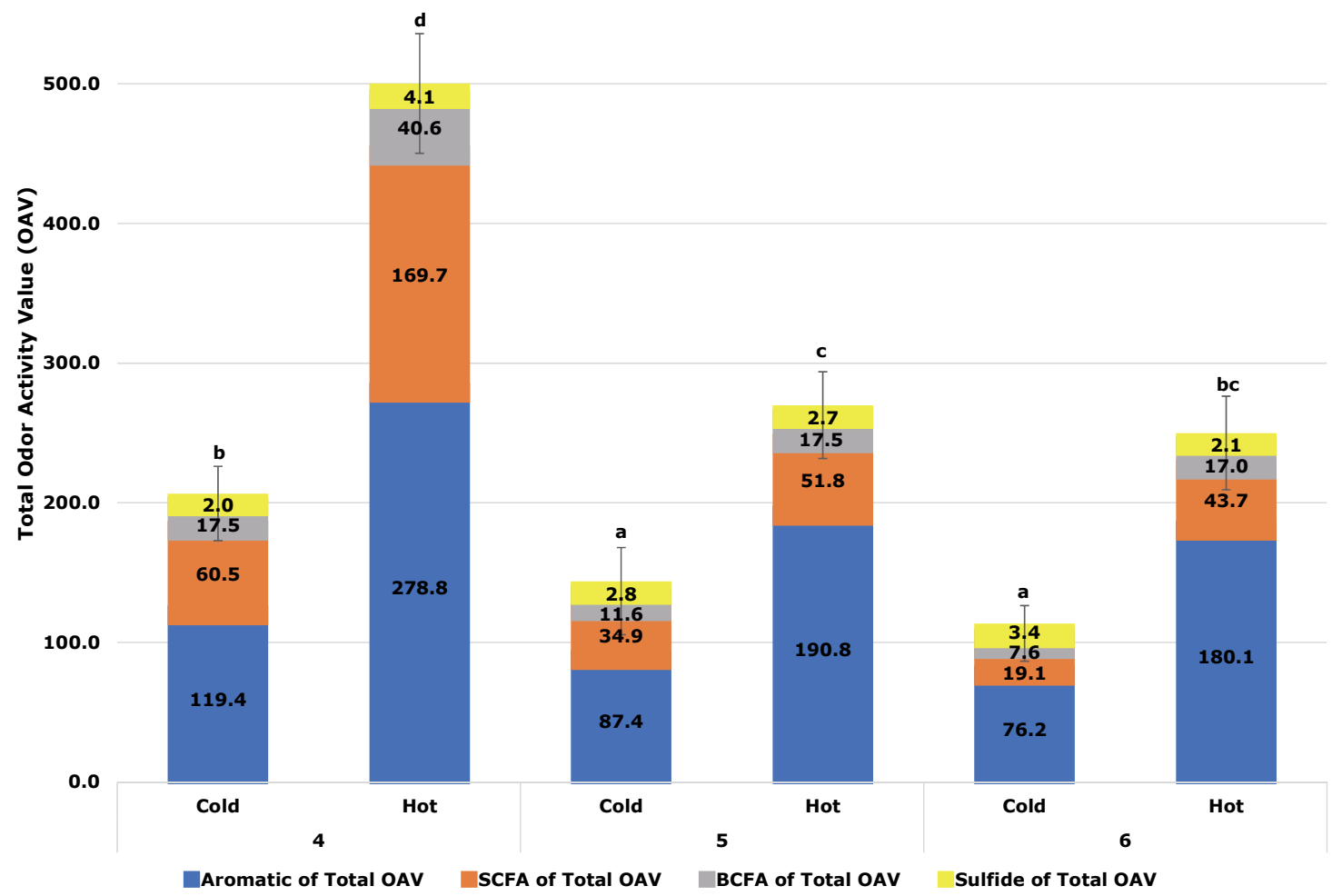

Figure 11. Calculated total odor activity value (OAV) delineated into aromatics, straight-chain fatty acids (SCFA), branched-chain fatty acids (BCFA), and sulfides for lab-scale bedded packs containing bean stover, corn stover, pine wood chips, and wheat straw. Ambient temperature $\times$ age of bedded pack treatment interaction $\mathbf{p}<\mathbf{0 . 0 0 0 1}$. Values are least squares means. Error bars indicate standard errors. Different letters indicate significant differences $(p<0.05)$.

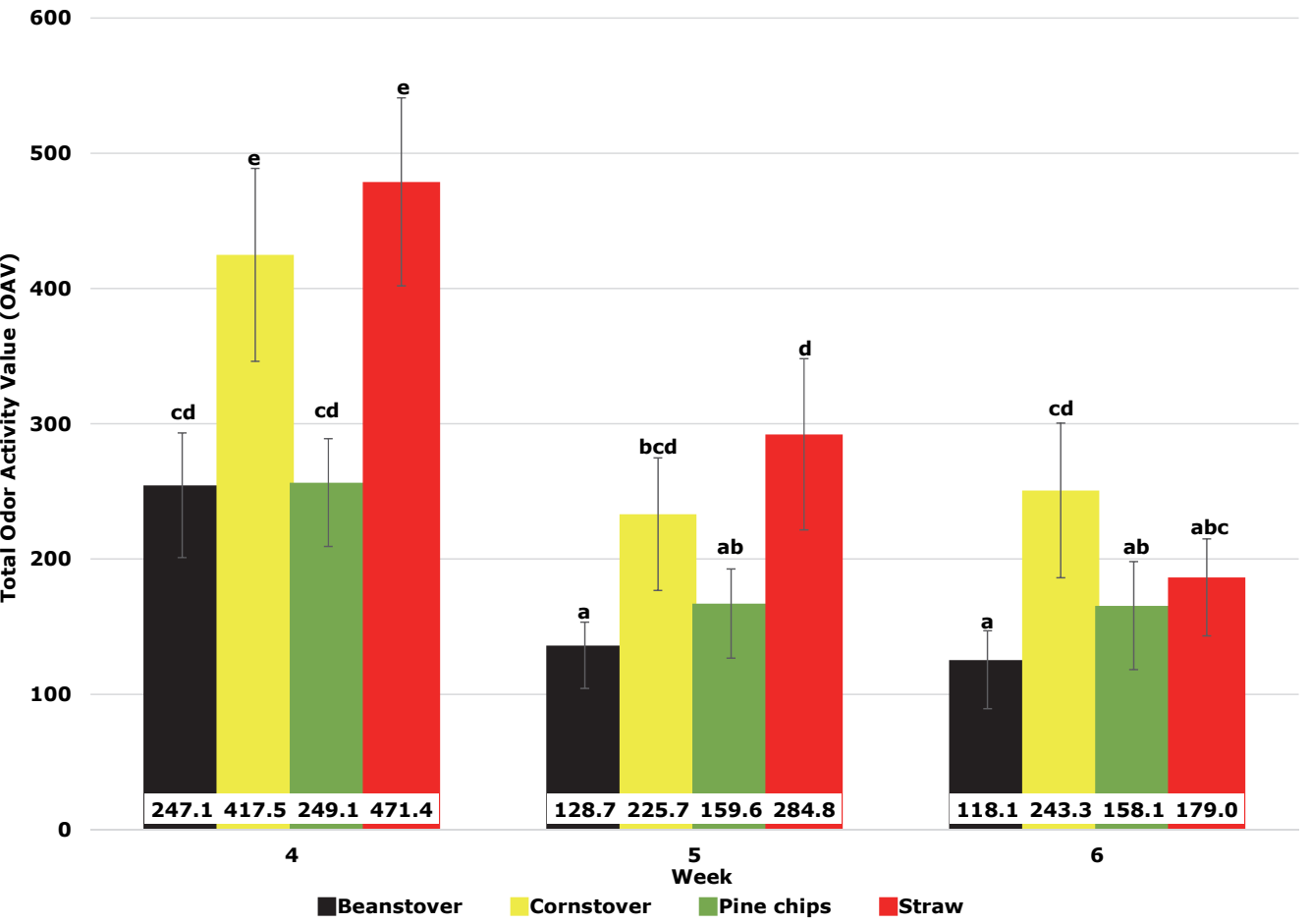

Figure 12. Calculated total odor activity value (OAV) for lab-scale bedded packs containing bean stover, corn stover, pine wood chips, and wheat straw over four 42-day periods. Bedding material $\times$ age of bedded pack treatment interaction $p=0.0255$. Values are least squares means. Error bars indicate standard errors. Different letters indicate significant differences $(p<0.05)$. 


\section{CONCLUSiOnS}

No significant three-way interactions for bedding material $\times$ ambient temperature $\times$ age of bedded pack were observed in the current study. Significant bedding material $\times$ ambient temperature interactions were observed for total aromatic compounds and total sulfide compounds. Total aromatic compounds were significantly $(p<0.0001)$ greater for $\mathrm{CS}$ and WS bedding materials in hot environments compared to BS and PC. While total aromatic compounds were lowest (87.09 $\left.\mathrm{ng} \mathrm{L}^{-1}\right)$ for BS across cold treatments, total sulfide compounds from cold-PC (51.69 $\left.\mathrm{ng} \mathrm{L}^{-1}\right)$ were significantly $(p=0.0143)$ greater than all other treatments. Within hot treatments, total sulfide compounds were similar across all bedding materials. A bedding material $\times$ ambient temperature interaction trend $(\mathrm{p}=0.0796)$ was observed for total OAV production. Considering that total aromatic compounds made up $72.6 \%$ of the total OAV production, BS and PC bedding materials would be most suitable for reducing noxious odors from bedded pack facilities. Additionally, BS and PC had the lowest total OAV across all weeks. Total OAV decreased over time for both hot and cold treatments, although cold treatments had significantly $(\mathrm{p}<0.0001)$ lower total OAV regardless of the age of bedded pack.

The results of this study indicate that feedlot operators maintaining bedded pack facilities will achieve the greatest overall odor reduction when using BS or PC bedding material, no matter the ambient temperature. During warm seasons, increasing the frequency of bedded pack removal and creating an aerobic compost environment may reduce overall odorous emissions. Consideration should be given to reducing the environmental temperature, when possible, when operating bedded pack facilities to reduce odor levels.

\section{ACKNOWLEDGEMENT}

The authors acknowledge Alan Kruger, Cindy Felber, and Sue Wise for their assistance with study construction, data collection, and data processing. This project was funded by appropriated funds from the USDA.

\section{REFERENCES}

Bouchard, R., \& Conrad, H. R. (1973). Sulfur requirement of lactating dairy cows: II. Utilization of sulfates, molasses, and lignin-sulfonate. J. Dairy Sci., 56(11), 1429-1434. https://doi.org/10.3168/jds.S0022-0302(73)85378-0

Brown-Brandl, T. M., Nienaber, J. A., \& Eigenberg, R. A. (2011). Temperature and humidity control in indirect calorimeter chambers. Trans. ASABE, 54(2), 685-692. https://doi.org/10.13031/2013.36471

Bulliner, E. A., Koziel, J. A., Cai, L., \& Wright, D. (2006). Characterization of livestock odors using steel plates, solidphase microextraction, and multidimensional gas chromatography-mass spectrometry-olfactometry. J. Air Waste Mgmt. Assoc., 56(10), 1391-1403. https://doi.org/10.1080/10473289.2006.10464547

DiSpirito, A. A., Zahn, J. A., Russell, D. W., Cooper, E. E., \& Hatfield, J. L. (1994). Development of a standardized method of odor quantification from livestock waste: Development of an odor index. Final Report 97-1994. Washington, DC: National Pork Producers Council.
Doran, B., Euken, R., \& Spiehs., M. (2010). Hoops and monoslopes: What we have learned about management and performance. In Feedlot Forum 2010 (pp. 8-16). Ames, IA: Iowa State University, Iowa Beef Center.

Euken, R., Doran, B., Clark, C. A., Shouse, S. C., Loy, D., \& Schulz, L. L. (2015). Beef feedlot systems manual. PM 1867. Ames, IA: Iowa State University Extension. Retrieved from $\mathrm{http}: / /$ lib.dr.iastate.edu/extension pubs/95

Friedrich, J. E., \& Acree, T. E. (1998). Gas chromatography olfactometry (GC/O) of dairy products. Intl. Dairy J., 8(3), 235241. https://doi.org/10.1016/S0958-6946(98)80002-2

Koziel, J. A., Cai, L., Wright, D. W., \& Hoff, S. J. (2006). Solidphase microextraction as a novel air sampling technology for improved, GC-olfactometry-based assessment of livestock odors. J. Chromatogr. Sci., 44(7), 451-457. https://doi.org/10.1093/chromsci/44.7.451

Mackie, R. I., Stroot, P. G., \& Varel, V. H. (1998). Biochemical identification and biological origin of key odor components in livestock waste. J. Animal Sci., 76(5), 1331-1342. https://doi.org/10.2527/1998.7651331x

Miller, D. N., \& Varel, V. H. (2001). In vitro study of the biochemical origin and production limits of odorous compounds in cattle feedlots. J. Animal Sci., 79(12), 2949-2956. https://doi.org/10.2527/2001.79122949x

Miller, J. J., Beasley, B. W., Yanke, L. J., Larney, F. J., McAllister, T. A., Olson, B. M., ... Hasselback, P. (2003). Bedding and seasonal effects on chemical and bacterial properties of feedlot cattle manure. J. Environ. Qual., 32(5), 1887-1894. https://doi.org/10.2134/jeq2003.1887

O’Neill, D. H., \& Phillips, V. R. (1992). A review of the control of odour nuisance from livestock buildings: Part 3. Properties of the odorous substances which have been identified in livestock wastes or in the air around them. J. Agric. Eng. Res., 53, 23-50. https://doi.org/10.1016/0021-8634(92)80072-Z

Parker, D. B. (2008). Reduction of odor and VOC emissions from a dairy lagoon. Appl. Eng. Agric., 24(5), 647-655. https://doi.org/10.13031/2013.25272

Parker, D. B., Gilley, J., Woodbury, B., Kim, K.-H., Galvin, G., Bartelt-Hunt, S. L., ... Snow, D. D. (2013b). Odorous VOC emission following land application of swine manure slurry. Atmos. Environ., 66, 91-100. https://doi.org/10.1016/j.atmosenv.2012.01.001

Parker, D. B., Ham, J., Woodbury, B., Cai, L., Spiehs, M., Rhoades, M., ... Cole, A. (2013a). Standardization of flux chamber and wind tunnel flux measurements for quantifying volatile organic compound and ammonia emissions from area sources at animal feeding operations. Atmos. Environ., 66, 72-83. https://doi.org/10.1016/j.atmosenv.2012.03.068

Parker, D. B., Hayes, M., Brown-Brandl, T., Woodbury, B., Spiehs, M., \& Koziel, J. A. (2016). Surface application of soybean peroxidase and calcium peroxide for reducing odorous VOC emissions from swine manure slurry. Appl. Eng. Agric., 32(4), 389-398. https://doi.org/10.13031/aea.32.11672

Parker, D. B., Koziel, J., Cai, L., Jacobson, L. D., Akdeniz, N., Bereznicki, S. D., ... Hetchler, B. P. (2012). Odor and odorous chemical emissions from animal buildings: Part 6 . Odor activity value. Trans. ASABE, 55(6), 2357-2368. https://doi.org/10.13031/2013.42498

Powers, W. J. (2001). Development of procedures for odor evaluation techniques. Proc. 1st IWA Intl. Conf. on Odour and VOCs: Measurement, Regulation, and Control Techniques. London, UK: International Water Association.

Spiehs, M. J. (2018). Lab-scale model to evaluate odor and gas concentrations emitted by deep bedded pack manure. $J$. Visualized Exp.(137). https://doi.org/10.3791/57332 
Spiehs, M. J., Berry, E. D., Wells, J. E., Parker, D. B., \& BrownBrandl, T. M. (2017). Odorous volatile organic compounds, Escherichia coli, and nutrient concentrations when kiln-dried pine chips and corn stover bedding are used in beef bedded manure packs. J. Environ. Qual., 46(4), 722-732. https://doi.org/10.2134/jeq2016.09.0333

Spiehs, M. J., Brown-Brandl, T. M., Berry, E. D., Wells, J. E., Parker, D. B., Miller, D. N., ... DiCostanzo, A. (2014). Use of wood-based materials in beef bedded manure packs: 2 . Effect on odorous volatile organic compounds, odor activity value, Escherichia coli, and nutrient concentrations. J. Environ. Qual., 43(4), 1195-1206. https://doi.org/10.2134/jeq2013.05.0165

Spiehs, M. J., Brown-Brandl, T. M., Parker, D. B., \& Miller, D. N. (2012). Effect of bedding material on air quality of bedded manure packs in livestock facilities. ASABE Paper No. 121337890. St. Joseph, MI: ASABE.

Spiehs, M. J., Brown-Brandl, T. M., Parker, D. B., Miller, D. N., Berry, E. D., \& Wells, J. E. (2013). Effect of bedding materials on concentration of odorous compounds and Escherichia coli in beef cattle bedded manure packs. J. Environ. Qual., 42(1), 6575. https://doi.org/10.2134/jeq2012.0251

Trabue, S. L., Anhalt, J. C., \& Zahn, J. A. (2006). Bias of tedlar bags in the measurement of agricultural odorants. J. Environ. Qual., 35(5), 1668-1677. https://doi.org/10.2134/jeq2005.0370
USDA. (2011). Carbon to nitrogen ratios in cropping systems. Greensboro, NC: USDA-NRCS East National Technology Support Center. Retrieved from https://www.nrcs.usda.gov/Internet/FSE_DOCUMENTS/nrcsep rd331820.pdf

van Gemert, L. J. (2003). Compilations of odour threshold values in air, water, and other media. Zeist, The Netherlands: Oliemans Punter \& Partners.

Woodbury, B. L., Gilley, J. E., Parker, D. B., Marx, D. B., \& Eigenberg, R. A. (2015). VOC emissions from beef feedlot pen surfaces as affected by within-pen location, moisture, and temperature. Biosyst. Eng., 134, 31-41. https://doi.org/10.1016/j.biosystemseng.2015.03.014

Wright, D. W., Eaton, D. K., Nielsen, L. T., Kuhrt, F. W., Koziel, J. A., Spinhirne, J. P., \& Parker, D. B. (2005). Multidimensional gas chromatography-olfactometry for the identification and prioritization of malodors from confined animal feeding operations. J. Agric. Food. Chem., 53(22), 8663-8672. https://doi.org/10.1021/jf050763b

Zhu, J. (2000). A review of microbiology in swine manure odor control. Agric. Ecosyst. Environ., 78(2), 93-106. https://doi.org/10.1016/S0167-8809(99)00116-4 